\title{
EDITORIAL
}

\section{Driving pressure in obese ventilated patients: another brick in the (chest) wall}

\author{
Thomas Bein* (1)
}

(0) 2018 Springer-Verlag GmbH Germany, part of Springer Nature and ESICM

The incidence of obesity is increasing worldwide, and obese or severely obese patients often present with several comorbidities. Obesity is associated with significant complications, and an increase in the mortality of obese patients after hospital admission compared to non-obese patients is justified [1]. The proportion of obesity in patients presenting with acute respiratory distress syndrome (ARDS) has not been investigated systematically, but data from the influenza A (H1N1) pandemic in 2009 suggested that obese patients were overrepresented compared to the general population [2]. The management of ARDS in patients with obesity is a special challenge, since obesity and severe obesity are associated with marked derangements in lung and chest wall mechanics [3].

In clinical studies on obese mechanically ventilated patients without lung injury [4] or with ARDS [5], specific changes in respiratory system mechanics were observed (Table 1). These findings may help develop a better understanding of a suitable ventilation strategy in obesity. In all studies, static respiratory compliance $\left(C_{\mathrm{st}, \mathrm{rs}}\right)$ was reduced with a rising level of obesity [expressed by body mass index (BMI)], while elastance (the reciprocal of compliance) tended to increase. These changes in $C_{\text {st,rs }}$ were due to compliance reduction in both parts of the respiratory system: the lung and the chest wall. In other words, during mechanical ventilation in obese patients, the lungs and predominantly the chest wall become 'stiffer'. This finding-observed in obese lung-healthy patients as well in ARDS patients-deserves attention and interpretation. Physiologically, the chest wall (rib cage and abdomen) is elastic, and the interaction between the lungs and the chest wall is finely balanced under spontaneous breathing [7]. The chest wall tends to expand outward, while the lungs tend to collapse. The 'mediator' between both is the pleural pressure. The reduction of chest wall compliance $\left(C_{\mathrm{st}, \mathrm{w}}\right)$ in obesity is mainly due to the increase of intraabdominal pressure in these patients [3], which results in a lower lung volume for the same pleural pressure.

In a large retrospective analysis of the data of 3562 ARDS patients from nine studies, Amato et al. [8] demonstrated that elevated driving pressure $(\Delta P)$, a parameter expressing the relation between tidal volume and functional lung size (compliance of the respiratory system) $=V_{\mathrm{T}} / C_{\mathrm{st}, \mathrm{rs}}$, was an independent ventilation variable strongly associated with increased mortality, while changes in tidal volume or positive end-expiratory pressure were not independent predictors of the outcome. An actual systematic review [9] reconfirmed the retrospective data of Amato et al. [8] by analysing the data of four prospective randomized studies (3252 patients): a higher $\triangle P$ was associated with a significantly higher mortality in ARDS patients. 
Table 1 Characteristics of respiratory mechanics in obese mechanically ventilated patients (findings from clinical studies)

\begin{tabular}{|c|c|c|c|c|c|c|}
\hline \multicolumn{2}{|l|}{ Study/patients } & \multicolumn{2}{|c|}{$\begin{array}{l}\text { Static respiratory system compli- } \\
\text { ance }\left(\mathrm{C}_{\mathrm{st}, \mathrm{rs}}\right)\left(\mathrm{mL} \mathrm{cm}_{2} \mathrm{O}^{-1}\right)\end{array}$} & \multicolumn{2}{|c|}{$\begin{array}{l}\text { Lung compliance }\left(C_{\mathrm{st}, \mathrm{L}}\right) \\
\left(\mathrm{mL} \mathrm{CmH}_{2} \mathrm{O}^{-1}\right)\end{array}$} & $\begin{array}{l}\text { Chest wall compliance }\left(C_{\mathrm{st}, \mathrm{w}}\right) \\
\left(\mathrm{mL} \mathrm{cmH}_{2} \mathrm{O}^{-1}\right)\end{array}$ \\
\hline \multicolumn{2}{|c|}{$\begin{array}{l}\text { Pelosi } 1996[4] \\
20 \text { pts., general anaesthesia }\end{array}$} & \multicolumn{2}{|c|}{$\begin{array}{l}\mathrm{BMI}<25=66 \pm 14 \\
\mathrm{BMI}>40=35 \pm 5\end{array}$} & \multicolumn{2}{|c|}{$\begin{array}{l}107 \pm 32 \\
55 \pm 15\end{array}$} & $\begin{array}{l}191 \pm 45 \\
112 \pm 47\end{array}$ \\
\hline \multicolumn{2}{|c|}{$\begin{array}{l}\text { Pelosi } 1998[5]^{*} \\
24 \text { pts., general anaesthesia }\end{array}$} & \multicolumn{2}{|c|}{$\begin{array}{l}\mathrm{BMl}<25 \approx 75 \\
\mathrm{BMI} 25-40 \approx 55 \\
\mathrm{BMI}>40 \approx 46\end{array}$} & \multicolumn{2}{|c|}{$\begin{array}{l}\approx 150 \\
\approx 85 \\
\approx 53\end{array}$} & $\begin{array}{l}\approx 250 \\
\approx 180 \\
\approx 110\end{array}$ \\
\hline \multicolumn{2}{|c|}{$\begin{array}{l}\text { Normal findings in spontaneously } \\
\text { breathing adult subjects [14] }\end{array}$} & \multicolumn{2}{|l|}{$50-100$} & \multicolumn{2}{|l|}{200} & $100-200$ \\
\hline Study/patients & \multicolumn{2}{|c|}{$\begin{array}{l}\text { Static respiratory system } \\
\text { elastance }\left(\mathrm{cmH}_{2} \mathrm{OL}^{-1}\right)\end{array}$} & Lung elastance $(\mathrm{cml}$ & $\left.\mathrm{OL}^{-1}\right)$ & $\begin{array}{l}\text { Chest wall elastance } \\
\left(\mathrm{cmH}_{2} \mathrm{OL}^{-1}\right)\end{array}$ & $\begin{array}{l}\text { Driving pressure }(\Delta P) \\
\left(\mathrm{cmH}_{2} \mathrm{O}\right)\end{array}$ \\
\hline $\begin{array}{l}\text { Chiumello } 2016 \text { [6] } \\
101 \text { ARDS patients }\end{array}$ & \multicolumn{2}{|c|}{$\begin{array}{l}\mathrm{BMI}<25=25(19-31) \\
\mathrm{BMI} 25-30=27(21-36) \\
\mathrm{BMI}>30=26(24-32)\end{array}$} & $\begin{array}{l}18(14-25) \\
21(16-30) \\
21(15-24)\end{array}$ & & $\begin{array}{l}5(3-9) \\
6(4-9) \\
8(4-10)\end{array}$ & $\begin{array}{l}11(10-14) \\
15(12-17) \\
14(13-17)\end{array}$ \\
\hline
\end{tabular}

$B M /$ body mass index

*Values estimated from figures

Surprisingly, this important finding seems not to be of value for obese ARDS patients. The retrospective analysis presented by de Jong et al. [10] on the impact of $\Delta P$ on 90-day mortality in 100 obese $(B M I \geq 30)$ and 262 non-obese ARDS patients revealed a significant relationship between $\Delta P$ and mortality only in non-obese patients. The $\Delta P$ on day 1 was significantly lower in non-obese ARDS patients $\left(11.9 \pm 4.2 \mathrm{cmH}_{2} \mathrm{O}\right)$ who had survived 90 days compared to non-obese non-survivors $\left(15.2 \pm 5.2 \mathrm{cmH}_{2} \mathrm{O}, p<0.001\right)$. In obese patients, the $\Delta P$ did not differ between survivors and non-survivors. Additionally, in a multivariate Cox analysis, $\Delta P$ was identified as an independent predictor of day 90 mortality in non-obese, but not in obese patients. Interestingly the mortality did not differ between non-obese (47\%) and obese ARDS (46\%) patients. Although the current study has some limitations (the monocentric and retrospective design), an important finding was that the day 1 mean values for $\Delta P$ were similar in the survivors $\left(13.7 \pm 4.5 \mathrm{cmH}_{2} \mathrm{O}\right)$ and in the non-survivors (13.2 $\left.\pm 5.1 \mathrm{cmH}_{2} \mathrm{O}, p=0.41\right)$, and on a level which has been identified as being within a 'safe' border. Amato et al. [8] described a $\Delta P$ of $15 \mathrm{cmH}_{2} \mathrm{O}$ as a threshold discriminating between a good outcome of ARDS patients (relative risk of death $\leq 1$ with $\Delta P \leq 15 \mathrm{cmH}_{2} \mathrm{O}$ ) and a higher risk of mortality with $\Delta P>15 \mathrm{cmH}_{2} \mathrm{O}$. The study by de Jong et al. [10] presented 'safe' $\Delta P$ levels $\left(\leq 15 \mathrm{cmH}_{2} \mathrm{O}\right)$ for the majority of obese ARDS patients. Is obesity per se a lung protective precondition generating low(er) $\Delta P$ values? If, yes, which are the specific (patho)physiologic mechanisms for such a distinction from non-obesity?

The reduction in $C_{\text {st,w }}$ is a characteristic finding in the respiratory mechanics of mechanically ventilated obese patients (Table 1), and this distinctiveness could be responsible for the lower $\Delta P$ values, as seen in the 'obesity paradox.' A meta-analysis on the causal relation between obesity and mortality in ARDS [11] evaluating the combined data of nine studies found that obesity was significantly associated with a reduced risk of ARDS mortality (pooled OR 0.63, 95\% CI 0.64-0.84). In consequence, further studies should carefully investigate the potential role of chest wall dynamics, pleural pressure and transpulmonary pressure in obesity with the aim of examining the hypothesis that adiposity offers a certain protection against ventilator-induced lung injury. Furthermore, the shape of obesity is various, and in recent years it was demonstrated that the pattern of body fat distribution (general or abdominal adiposity) has a great impact on outcomes. Reis et al. [12] reported that in middle-aged healthy persons, higher values of the waist-to-thigh ratio (in both sexes) or the waist-to-hip ratio (in women) were positively associated with increased mortality, while the BMI exhibited U- or J-shaped associations. In intensive care, no data exists on the pattern of obesity, and in future researchers should investigate not only BMI but also the effects of abdominal obesity on outcomes.

Are the results of the study by de Jong et al. [10] a setback for those who found in the parameter $\Delta P$ (easily assessed at the bedside!) a new tailor-made solution for an individualized lung protective ventilation strategy in all ARDS patients? No, quite the opposite! The data from de Jong et al. provides an important step forward to a personalized strategy in intensive care medicine [13]. Again, it becomes clear that a simple 'one variable fits all' will not work in critical care. 


\section{Compliance with ethical standards}

\section{Conflicts of interest}

The author declares no conflict of interest.

Received: 19 June 2018 Accepted: 20 June 2018

Published online: 29 June 2018

\section{References}

1. Adams KF, Schatzkin A, Harris TB, Kipnis V, Mouw T, Ballard-Barbash R, Hollenbeck A, Leitzmann MF (2006) Overweight, obesity, and mortality in a large prospective cohort of persons 50 to 71 years old. N Engl J Med 355:763-778

2. Morgan OW, Bramley A, Fowlkes A, Freedman DS, Taylor TH, Gargiullo P, Belay B, Jain S, Cox C, Kamimoto L, Fiore A, Finelli L, Olsen SJ, Fry AM (2010) Morbid obesity as a risk factor for hospitalization and death due to 2009 pandemic influenza A (H1N1) disease. PLoS One 5:e9694

3. Pelosi P, Luecke T, Rocco PR (2011) Chest wall mechanics and abdominal pressure during general anaesthesia in normal and obese individuals and in acute lung injury. Curr Opin Crit Care 17:72-79

4. Pelosi P, Croci M, Ravagnan I, Vicardi P, Gattinoni L (1996) Total respiratory system, lung, and chest wall mechanics in sedated-paralyzed postoperative morbidly obese patients. Chest 109:144-151

5. Pelosi P, Croci M, Ravagnan I, Tredici S, Pedoto A, Lissoni A, Gattinoni L (1998) The effects of body mass on lung volumes, respiratory mechanics, and gas exchange during general anesthesia. Anesth Analg 87:654-660
6. Chiumello D, Colombo A, Algieri I, Mietto C, Carlesso E, Crimella F, Cressoni M, Quintel M, Gattinoni L (2016) Effect of body mass index in acute respiratory distress syndrome. Br J Anaesth 116:113-121

7. Hess DR, Bigatello LM (2008) The chest wall in acute lung injury/acute respiratory distress syndrome. Curr Opin Crit Care 14:94-102

8. Amato MB, Meade MO, Slutsky AS, Brochard L, Costa EL, Schoenfeld DA Stewart TE, Briel M, Talmor D, Mercat A, Richard JC, Carvalho CR, Brower RG (2015) Driving pressure and survival in the acute respiratory distress syndrome. N Engl J Med 372:747-755

9. Aoyama H, Pettenuzzo T, Aoyama K, Pinto R, Englesakis M, Fan E (2018) Association of driving pressure with mortality among ventilated patients with acute respiratory distress syndrome: a systematic review and metaanalysis. Crit Care Med 46:300-306

10. de Jong A, Cossic J, Verzilli D, Monet C, Carr J, Conseil M, Monnin M, Cisse M, Belafia F, Molinari M, Chanques G, Jaber S (2018) Impact of the driving pressure on mortality in obese and non-obese ARDS-patients: a retrospective study of 362 cases. Intensive Care Med. https://doi.org/10.1007/ s00134-018-5241-6

11. Zhi G, Xin W, Ying W, Guohong X, Shuying L (2016) "Obesity paradox" in acute respiratory distress syndrome: asystematic review and meta-analysis. PLoS One 11:e0163677

12. Reis JP, Macera CA, Araneta MR, Lindsay SP, Marshall SJ, Wingard DL (2009) Comparison of overall obesity and body fat distribution in predicting risk of mortality. Obesity 17:1232-1239

13. Wong HR (2017) Intensive care medicine in 2050: precision medicine. Intensive Care Med 43:1507-1509

14. Galetke W, Feier C, Muth T, Ruehle KH, Borsch-Galetke E, Randerath W (2007) Reference values for dynamic and static pulmonary compliance in men. Respir Med 101:1783-1789 